\title{
Islamic Charities in Australia and the Governance Predicaments
}

\author{
Nur Farahiah Azmi, Hazriah Hasan* \& Mohd Nor Hakimin Yusoff \\ Faculty of Entrepreneurship and Business, \\ Universiti Malaysia Kelantan, Kota Bharu, Malaysia. \\ Email: hazriah.h@umk.edu.my \\ DOI: https://doi.org/10.37134/jcit.vol10.sp.1.2020
}

Cite this paper (APA): Hasan, H., Azmi, N. F., \& Yusoff, M. N. H. (2020). Islamic Charities in Australia and the Governance Predicaments. Journal of Contemporary Issues and Thought, 10, 1-9. https://doi.org/10.37134/jcit.vol10.sp.1.2020

\begin{abstract}
Islamic charity is one of the groups under the third sector or non-profit sector that mainly came out as a focal point in some countries. These Islamic charities made a significant contribution in various aspects in terms of religious, economic and social aspects. However, there are several issues and complexities faced by Islamic charities. Thus, this paper focuses on discussing Islamic charities in Australia through reviewing related literature. This paper also identifies some of the predicaments faced by Islamic charities and explores the authorities that may monitor the management and operation of Islamic charities. The findings of this paper offer insight for future researchers on possible solutions for governance.
\end{abstract}

Keywords: Islamic Charity; Governance Predicaments; Non-profit Sectors

\section{Introduction}

For centuries, third or non-profit sectors have played a significant role as the provider to several services such as health, education, culture, civic engagement and many more. The Australian not-for-profit industry also not in the exception. The latest ACNC Australian Charities Report 2017 informed that Australian charities had a total income of $\$ 149.9$ billion with more than 400,000 volunteers involved in the charities' programmes. The culture of volunteering creates a positive perception among the society, not only inculcate their family members to join the voluntary work, but it develops the sense of helping others.

One of the groups under the third sector or non-profit sector that mainly came out as a focal point in some countries is religious charity. From the ACNC Australian Charities Report 2017, it is highlighted that the most common activity of the charity is religion (Australian Charities and Not-for-profits Commission [ACNC], 2017). In addition, previous studies also mentioned about significance of 
contributions of Islamic charity such as religious and spiritual aspects (Ali \& Hatta, 2014), economic aspect (Yumna, 2019; Moghul, 2017) and social aspect (Abdullahi, 2019; Mohsin et al., 2016). Despite various significant contributions of Islamic charity in various aspects, yet there is an increased demand for how the Australian charities use their funds effectively (Furneaux \& Wymer, 2015). The loose of governance practices in Islamic charities leads to a negative impact in delivering and meeting their social missions to its stakeholders. Thus, the limelight of the paper is towards the development and management of Islamic charities in Australia. Perhaps, by reviewing past studies on the issues pertaining to the Islamic charities, this paper will be able to notify related authorities to aid these Islamic charities in terms of advocacy and regulation.

In the next section, the discussion on the previous literature on the background, definition, management and legal framework of Islamic charity are presented. The third section of this paper provides a lengthy discussion of governance issues and scandals faced by Islamic charities in Australia. Then, the next section presents the discussion on the authorities' bodies for Islamic charity in Australia. The final section draws conclusion from the previous section and concludes the study.

\section{Literature Review}

\section{Background of Islamic charity in Australia}

The history of charity in Australia started due to charity's regulation reform (Mcgregor-Lowndes, 2016). It commenced first in 1995, where the report by Industry Commission was lodged. The event followed by requesting Charity Definition in 2001. Then, it leads to the establishment of Australian Charities and Not-for-Profit Commission (ACNC) and Charities Act 2013 (Mcgregor-Lowndes, 2016).

The pioneering study on the history of Muslim societies and organisations is conducted by (Cleland, 2002). The study reported that Muslim organisation and societies started from scratch because of the declining numbers of the Muslim population during the 1920s onwards due to the introduction of Australian Federation in 1901. In addition, the development of railways also one of the factors of the declining numbers of Afghan camel drivers also declined. After World War II, the revised Migration Act is more "open" in welcoming the immigrants and refugees. As a result of the end of the White Australia policy, a growing Muslim community after the civil war in Lebanon and about 17000 Lebanese Muslims reported arrived in Australia (Cleland, 2002). 
The establishment of Muslim organisation commenced with Islamic Society of Victory in 1957 followed by the establishment of the Australian Federation of Islamic Society (AFIS) in 1964. AFIS is built through the efforts of Muslim leaders such as Fehmi al-Imam, Abdul Khaliq Kazi and Ibrahim Delal and others. The focal point of Muslim organisation in Australia was in 1974 during the visit of two delegations from Dr Ali Ketani (adviser to King Faisal) and Dr Abdullah al Zayed from Saudi Arabia. The meeting acknowledged the need for a national organisation that serves as one umbrella to unite the Muslim communities. During the meeting, there were four recommendations proposed, however, only two suggestions were agreed to bring into effect such as:

1. The development of an Islamic Council in each state or territory to represent the Muslim population of such state or territory.

2. The affiliation of state Councils into a federation at the national level.

The history of charity in Australia started due to charity's regulation reform (Mcgregor-Lowndes, 2016). It commenced first in 1995 where the report by Industry Commission was lodged. The event followed by requesting Charity Definition in 2001, then, it leads to the establishment of Australian Charities and Not-for-Profit Commission (ACNC) and Charities Act 2013 (Mcgregor-Lowndes, 2016).

The pioneering study on the history of Muslim societies and organisations is conducted by Cleland (2002). The study reported that Muslim organisation and societies started from scratch because of the declining numbers of the Muslim population during the 1920s onwards due to the introduction of Australian Federation in 1901. In addition, the development of railways is one of the factors of the declining numbers of Afghan where camel drivers declined. After World War II, the revised Migration Act is more "open" in welcoming the immigrants and refugees. As a result of the end of the White Australia policy, a growing Muslim community after the civil war in Lebanon and about 17000 Lebanese Muslims reported arrived in Australia (Cleland, 2002).

The establishment of Muslim organisation commenced with Islamic Society of Victory in 1957 followed by the establishment of the Australian Federation of Islamic Society (AFIS) in 1964. AFIS is built through the efforts of Muslim leaders such as Fehmi al-Imam, Abdul Khaliq Kazi and Ibrahim Delal and others. The focal point of Muslim organisation in Australia was in 1974 during the visit of two delegations from of Dr Ali Ketani (adviser to King Faisal) and Dr Abdullah al Zayed from Saudi Arabia. The meeting acknowledged the need for a national organisation that serves as one umbrella to unite the Muslim communities. During the meeting, there were four recommendations proposed, however, only two suggestions were agreed to bring into effect such as: 
1. The development of an Islamic Council in each state or territory to represent the Muslim population of such state or territory.

2. The affiliation of state Councils into a federation at the national level.

The definition of Islamic charity

In Australia, Charities Act (2013) refers to charity as:

"that is a not-for-profit entity; and all of the purposes of which are charitable purposes or purposes that are incidental or ancillary to, and in furtherance or aid of, purposes of the entity; none of the purposes of which are disqualifying and that is not an individual, a political party or a government entity". ( $p .4$ )

This definition came into effect in 2014 which highlighted the statutory definition of charity and charitable purpose. Moreover, the eligibility of such an entity to be registered as a charity in Australia will be assessed using the definition provided by the Charities Act (ACNC, 2013).

As per Islamic charity definition, there is no consensus on the exact meaning of an Islamic charity in Australia. In the recent study on faith-based charities in Australia, Knight and Gilchrist (2015) identified four groups of charity involved with religious purpose or activity which refer to ACNC. First, the charity is designated as a faith-based charity if the selection of charitable purpose as "advancement of religion". Next, the classification of the main activity as "religious activity" and indicated "other activity" field as "religious". Finally, "basic religious charity" category in which a charity has a sole charity subtype of "advancement religion" out of 14 categories of charity (ACNC, 2013).

Furthermore, Swain (2016) highlighted that definitions of a faith-based charity differ between nations. The previous study has discussed the definition of an Islamic charity in their country. For example, Saggiomo (2011) refers to Islamic charity as formal and informal organisations which based on Islamic faith in performing the unpaid community works. In Jordan, Islamic charity claimed that the organisation is a voluntary organisation which is providing social services without any intention of financial, personal and political gains which the Islamic charity is focusing on the missionary work (Wiktorowicz and Farouki, 2010).

\section{Management and Legal framework of Australian Islamic charities}

Charities are governed under Australian Charities and Not-for-profits Commission Act 2012. Furthermore, the registered charity under ACNC must oblige the ACNC governance standards in order to maintain its registration. The examination of the ACNC Governance standards No. 5 on Duties of responsible persons has outlined 
seven duties for the responsible person of such charity. The lists of the duties aimed to guide the members of the charity to act diligently and honestly (ACNC, 2013).

Apart from the ACNC obligation, the registered charities also have other obligations due to four reasons:

- concessions, exemptions or other benefits it may receive from other government agencies (for example, for certain Commonwealth, territory and local government taxes)

- its legal structure (for example, as an incorporated association or company limited by guarantee)

- the way it raises money (for example, grants or fundraisings such as street collections or raffles), and

- how it operates and what it does, for example, specific sectors such as aged care, housing, childcare and education have other reporting requirements, as do charities who receive grants from the government).

(ACNC, 2013)

The next discussion is on the legal structure of the registered charity in Australia. According to (ACNC Commission 2013), there are four commonly used of legal structure for charity with an incorporated structure such as:

- incorporated associations (the most common type) - the name will be something like 'XYZ Incorporated' or 'XYZ Inc.'

- companies limited by guarantee (the next most common structure) - for example, 'XYZ Limited' or "XYZ Ltd.'

Furthermore, the selection of legal status of such charity will affect the legal identity, governance structure, responsible persons, reporting and other compliances of its charity (ACNC, 2013). For example, the registered Islamic charities under incorporated legal status need to report their annual financial statement based on their charity's sizes.

According to Parkinson (2004), the unique form of the non-profit organisation is incorporated association where "the purpose of this organisation was to simplify the management of the societies established for the public goods so that the society can hold the party rather than it being vested in proprietors or trustees". As for the incorporation association, the legislation of governing operation of a non-profit organisation is different for each state. As for Victoria state, there are five main duties of committee members under the Associations Incorporations Acts such as improper use of information or position, a duty of care and diligence, duty of good faith and proper use, reliance of information, and indemnity of officeholders (Associations Incorporation Reform Act, 2012) 


\section{Predicaments of Islamic Charities in Australia}

There has been a number of significant governance issues towards Islamic charities in Australia. An example of a severe governance scandal faced by an Islamic charity in Australia was the case of the Australian Federation of Islamic Councils (AFIC), founded in 1964. As the national advocate at the state and territory level, this wrongdoing has drawn a lot of attention from the government and society. In the past, AFIC experienced "complicated" issues. The Woodward Royal Commission reported that AFIC involved malpractice management such as the ineffective management of the halal certification system. Furthermore, Wills and Harris (1994) mentioned that AFIC "meat-species scandal" caused great losses for the exporter due to the mistrust in the quality of Australian export products. The issue of AFIC continued in 2012. AFIC had allegedly misused the funds of Malek Fahd's schools. Safi and Farrell (2016) reported that the school's funds were transferred to AFIC as "management fees" for the non-existence of services and costs on rental were inflated. As a consequence, the Malek Fahd Islamic School had been ordered to pay $\$ 9$ million in public funds to New South Wales government, hence continued to be ineligible for the fund from state government (Shanahan, 2012). In 2016, a letter of Australia Charities and Not-for-profits Commissions (ACNC) to AFIC hit the fan as the letter stated that AFIC failed to comply with several ACNC governance standards (ACNC, 2016). ACNC highlighted that AFIC failed to comply with ACNC governance standards regarding the following reasons:

1) Impropriate use of funds by responsible persons of AFIC for personal benefits such as lawyer's fees and overseas trips.

2) Lack of accountability and transparency to the members and public due to failure in answering ACNC inquiries regarding the use of AFIC funds by their responsible person for the personal benefits.

3) Failure to take reasonable steps to ensure its responsible persons are subject to and comply with the duties expected of them.

Furthermore, Islamic charities in Australia are proclaimed to be involved in money laundering and terrorism financing. A report by the Australian Institute of Criminology stated that the Islamic charities had been put under certain scrutiny due to the unregulated donation process and minimal practices of transparency and accountability (Bricknell et al., 2011). Moreover, the prior research argues that the reasons for misdiverted revenue are due to the absence of government oversight and the divergence of charities' operation (Crimm, 2008; Ndiaye, 2007). 


\section{Authority Bodies for Islamic Charities in Australia}

\section{Australian Charities and Not-for-profits Commissions (ACNC)}

In 2012, the Australian government established a national regulator for not-forprofit organisations, called the Australian Charities and Not-For-Profit Commission (ACNC). This formation is a government's response towards the formal parliamentary inquiries related to accountability and transparency issues in the charities. ACNC plays a significant role in facilitating charities by adding the value of governance policies and standards of not-for-profit organisations. Furthermore, the ACNC also acts as a "one-stop-shop" platform for disseminating information relating to charities, registration guidelines and regulatory obligations (Public Administration Select Committee, 2012). ACNC has outlined five governance standards for Australian charities and not-for-profit organisations in order for them to be legally registered.

Australian Federal of Islamic (AFIC)

The formation of the AFIC was first based in Melbourne during 1976 before moved to Sydney (Cleland, 2002). Furthermore, Faris and Parry (2011) discussed the Islamic organisation in Australia. The study mentioned about Australian Federation of Islamic Council (AFIC) at the national level which played a role as the umbrella for the other Islamic organisation in Australia. At the state and territory level, there is each council which is acts as the representative of the broader Muslim community. The early focus of AFIC is to unite all Muslim organisations under one roof. Then, the role of AFIC is diversified which AFIC become a halal certification body and a support system for the establishment of Islamic schools (Cleland, 2002). AFIC also was known as Muslim Australia, and it has been registered as a large charity which is located in New South Wales. AFIC applied the multicultural slogan as "Diversity within the unity of Islam" in describing one of its organisational uniqueness which is ethnic diversity. In addition, the current vision of AFIC as stated on its website is:

"To empower Muslims through its constituent State, Territory Islamic Councils and Societies to achieve their full potential as Australian citizens."

(AFIC, 2019)

\section{Conclusion}

A list of issues and problems faced by Islamic charities that arise from the above discussions has pointed away for future research. Good governance practice offers 
positive results to facilitate the non-profit organisation to meet the challenges and deliver their social objectives (Arshad et al., 2014). In the case of Islamic charities in Australia, governance standards recommended by Australian Charities and NFP Commissions (ACNC) is one of best practice that can add value to NFP governance (Chelliah et al., 2015). Thus, this study calls for further research in this area.

\section{References}

Abdullahi, S.I. (2019). Zakah as tool for social cause marketing and corporate charity: a conceptual study. Journal of Islamic Marketing, 10(1), 191-207.

Ali, I., \& Hatta, Z.A. (2014). Zakat as a Poverty Reduction Mechanism Among the Muslim Community: Case Study of Bangladesh, Malaysia, and Indonesia. Asian Social Work and Policy Review, 8(1), 59-70.

Arshad, R., Razak, H.A., \& Bakar, N.A. (2014). Assessing the self-governance and value creation in non-profit organisations. Procedia-Social and Behavioral Sciences, 145, $286-293$.

Associations Incorporation Reform Act. (2012). Associations Incorporation Reform Act 2012. Canberra.

Australian Charities and Not-for-profits Commision. (2013). Governance for good: The ACNC's guide for charity board members. Australian Government. Melbourne.

Australian Charities and Not-for-profits Commision. (2016). Annual Information Statement Guide for medium and large charities. Australian Government. Melbourne.

Australian Charities and Not-for-profits Commision. (2017). ACNC Australian Charities Report. Australian Government. Melbourne.

Australian Foundation Investment Company. (2019). The Australian Federation of Islamic Councils. Retrieved from http://muslimsaustralia.com.au/. September 11, 2019.

Bricknell, S., McCusker, R., Chandwick, H \& Rees, D. (2011). Money laundering and terrorism financing risks to Australian non-profit organisations. AIC reports. Research and Public Policy Series 114. Retrieved from http://www.aic.gov.au

Cleland, B. (2002). Muslims in Australia : A brief history. Melbourne: Islamic Council of Victoria.

Crimm, N.J. (2008). The moral hazard of Anti-Terrorism Financing Measures: A potential to compromise civil societies and national interest. Wake Forest Law Review, 43, 577-626.

Faris, N., \& Parry, K. (2011). Islamic organizational leadership within a Western society: The problematic role of external context. The Leadership Quarterly, 22(1), 132-151.

Furneaux, C., \& Wymer, W. (2015). Public trust in Australian charities: Accounting for cause and effect. Third Sector Review, 21(2), 99. Retrieved from http://search.informit.com.au/documentSummary;dn=710497957462155;r es=IELAPA

Knight, P., \& Gilchrist, D. (2015). Australia's Faith-based Charities 2013: A summary of data from the Australian Charities 2013 Report, for the Australian Charities and Not-for-profits Commission, Melbourne.

Moghul, U. F. (2017). Islamic Spirituality: An Impetus to Responsibility and Impact. In A Socially Responsible Islamic Finance (pp. 1-37). Palgrave Macmillan, Cham.

Mohsin, M.I.A., Dafterdar, H., Cizakca, M., Alhabshi, S.O., Razak, S.H.A., Sadr, S.K., ... \& Obaidullah, M. (2016). Financing the Development of Old Waqf Properties: Classical Prinsiples and Innovative Practices around the World. Palgrave Studies In Islamic Banking, Finance, and Economics. Palgrave Macmillan. Springer Nature: New York.

Mcgregor-Lowndes, M. (2016). Lawyers, reform and regulation in the Australian third sector. Third Sector Review, 22(2), 33-44. 
Ndiaye, A. (2007). Islamic Charities in Switzerland and the Practice of Zakat. Program for The Study of International Organisations: Geneva.

Parkinson, C. (2004). Duties of Committee Members under the Associations Incorporation Acts. Monash UL Rev., 30, 75.

Public Administration Select Committee. (2012). The role of the Charity Commission and 'public benefit': Postlegislative scrutiny of the Charities Act 2006. HC, 13, 76.

Safi, M \& Farrell, P. (2016). Watchdog Investigates Claims Islamic Charity Funds Went on Personal Travel and Lawyers. Support the Guardian. United Kingdom. https://www.theguardian.com/society/2016/feb/12/watchdog-investigates-claims-islamiccharity-funds-went-on-personal-travel-and-lawyers

Saggiomo, V. (2011). From charity to governance: Islamic NGOs and education in Somalia. The Open Area Studies Journal, 4(1), 53-61.

Shanahan, L. (2012). Malek Fahd Islamic School to Repay $\$ 9 \mathrm{~m}$ in Public. The Australian. https://www.theaustralian.com.au/national-affairs/state-politics/malek-fahd-islamic-schoolto-repay-9m-in-public-funds/news-story/fe6ca8b8f08b445b0ef91992c4c11136

Steinberg, M., \& Cain, L. (2004). Managing An Ageing Third Sector Workforce : International snd local perspectives. Third Sector Review.

Swain, S. (2016). A Long History of Faith-Based Welfare in Australia: Origins and Impact. Journal of Religious History 41(41), 81-96.

Wiktorowicz, Q., \& Farouki, S. (2010). Islamic NGOs and Muslim politics: a case from Jordan. Third World Quarterly, 21(4), 685-699.

Wills, I., \& Harris, J. (1994). Government Versus Private Quality Assurance For Australian Food Exports. Australian Journal of Agricultural Economic, 38(1), 77-92.

Yumna, A. (2019). Islamic charity based micro-finance: lessons from Indonesia. In Third Padang International Conference On Economics Education, Economics, Business and Management, Accounting and Entrepreneurship (PICEEBA 2019). Advanced in Economics, Business and Management Research, 97. Atlantis Press. 